\title{
Characterization of Saccharomycopsis lipolytica Mutants Producing Lowered Levels of Alkaline Extracellular Protease
}

\author{
By DAVID M. OGRYDZIAK, ${ }^{*}$ SUK-CHUN CHENG AND STEPHEN J. \\ $\mathrm{SCHARF} \dagger$ \\ Institute of Marine Resources, University of California, Davis, California 95616, U.S.A.
}

(Received 24 November 1981; revised 10 March 1982)

\begin{abstract}
Mutants affected in production of alkaline extracellular protease (xpr mutants) have been characterized. The alkaline protease produced by the xpr mutants, except for that of the structural gene mutant, was indistinguishable from the wild-type protease on the basis of isoelectric focusing in polyacrylamide gels, SDS-PAGE and thermal stability. Some revertants of $x p r$ mutants were temperature sensitive for protease production, but the thermal stability of the revertant protease was not altered. The $x p r$ mutants grew as rapidly as the wild-type with glutamic acid, leucine or urea as sole nitrogen source. The pleiotropic xpr mutants which produced lowered levels of extracellular RNAase also produced less extracellular acid proteases (4 to $40 \%$ of wild-type). These results suggest that the pleiotropic $x p r$ mutants may affect secretion. However, production of phosphatase(s) (which was secreted but located primarily in the cell envelope) was much less affected in these mutants (65 to $100 \%$ of wild-type). A possible explanation for these results is that at least one step (component) of the secretion pathway for the extracellular proteases and RNAases is not shared by the phosphatase(s).
\end{abstract}

\section{INTRODUCTION}

Saccharomycopsis lipolytica and Saccharomyces cerevisiae are yeasts which have been used for studies of protein secretion. These yeasts are amenable to both biochemical and genetic analyses, and the power of such a combined approach for the study of protein secretion has been demonstrated in the studies of secretory mutants of Sacch. cerevisiae by Schekman and coworkers (Novick \& Schekman, 1979; Novick et al., 1980; Esmon et al., 1981; Novick et al., 1981). These studies established that proteins to be secreted by Sacch.cerevisiae are synthesized on the rough endoplasmic reticulum, transported through a Golgi-like structure, further transported to the cell surface in vesicles and then released. Saccharomycopsis lipolytica and Sacch. cerevisiae are not closely related (Nakase \& Komagata, 1968; Stenderup \& Leth Bak, 1968) and there may be interesting differences in the biology of secretion in these organisms. For example, most of the secreted proteins of Sacch. cerevisiae which have been studied remain in the cell envelope (Lampen, 1968), whereas, for several of the enzymes secreted by $S$. lipolytica substantial activity is found outside the cell envelope in the external medium (Ogrydziak \& Mortimer, 1977).

Mutations (xpr) in at least 16 genes result in a decrease in the production of the alkaline extracellular protease of the yeast S. lipolytica (Ogrydziak \& Mortimer, 1977; Mehta \& von Borstel, 1979). One of these genes is the structural gene for the protease (Simms \& Ogrydziak, 1981). Mutations in at least four of the xpr genes also reduce production of extracellular RNAase(s) (Ogrydziak \& Mortimer, 1977). In addition to the structural gene, the xpr mutations could be in regulatory genes or in genes involved in the processing and secretion of the extracellular protease. In an attempt to define their roles in extracellular protease production, we have further characterized the xpr mutants.

† Present address: Cetus Corporation, 600 Bancroft Way, Berkeley, California 94702, U.S.A. 


\section{METHODS}

Strains. Isolation and initial characterization of the xpr mutants has been described (Ogrydziak \& Mortimer, 1977). The parental strain was Saccharomycopsis lipolytica CX161-1B ade1 A (ATCC 32338).

Media. Acidified YM contained $0.3 \%(\mathrm{w} / \mathrm{v})$ each of yeast extract and malt extract, $0.5 \%(\mathrm{w} / \mathrm{v})$ peptone and $1 \%$ (w/v) glucose adjusted to $\mathrm{pH} 4.5$ with HCl. GPP (pH 3.4) medium contained (per litre): 6.7 g glycerol, $1.6 \mathrm{~g} \mathrm{Difco}$ Proteose-peptone, $1.7 \mathrm{~g}$ Difco Yeast Nitrogen Base (YNB) without amino acids and ammonium sulphate, $30 \mathrm{mg}$ adenine and $1 \mathrm{ml}$ polypropylene glycol, mol. wt 2000 (Polysciences) in $40 \mathrm{~mm}$-citrate buffer pH 3.4. Preparation of YM and GPP medium at pH 6.8 has been described (Ogrydziak \& Mortimer, 1977). Synthetic minimal (SM plus adenine) medium contained (per litre): $2 \mathrm{~g}$ glucose, $0.67 \mathrm{~g}$ YNB without amino acids, $30 \mathrm{mg}$ adenine and $1 \mathrm{ml}$ polypropylene glycol, mol. wt 2000 . Low phosphate agar medium was similar except that $0.1 \mathrm{~g} \mathrm{KNO}_{3}$ was substituted for the $\mathrm{KH}_{2} \mathrm{PO}_{4}$ in the YNB without amino acids, $\mathrm{pH}$ was adjusted to 4 with $\mathrm{HCl}$ and $2 \%$ (w/v) agar was added (Hansche et al., 1978). Low phosphate liquid medium contained the following (per litre): $10 \mathrm{~g}$ glycerol, $0 \cdot 1 \mathrm{~g}$ $\mathrm{CaCl}_{2} .2 \mathrm{H}_{2} \mathrm{O}, 0.1 \mathrm{~g} \mathrm{NaCl}, 0.5 \mathrm{~g} \mathrm{MgSO}_{4} .7 \mathrm{H}_{2} \mathrm{O}, 0.1 \mathrm{~g} \mathrm{KNO}_{3}, 5 \mathrm{~g}\left(\mathrm{NH}_{4}\right)_{2} \mathrm{SO}_{4}, 0.5 \mathrm{mg} \mathrm{H} \mathrm{HO}_{3}, 0.04 \mathrm{mg} \mathrm{Cu}-$ $\mathrm{SO}_{4} .5 \mathrm{H}_{2} \mathrm{O}, 0.1 \mathrm{mg} \mathrm{KI}, 0.2 \mathrm{mg} \mathrm{FeCl}{ }_{3} .6 \mathrm{H}_{2} \mathrm{O}, 0.4 \mathrm{mg} \mathrm{MnSO}{ }_{4} . \mathrm{H}_{2} \mathrm{O}, 0.2 \mathrm{mg} \mathrm{Na}_{2} \mathrm{MoO}_{4}, 0.4 \mathrm{mg} \mathrm{ZnSO}{ }_{4} .7 \mathrm{H}_{2} \mathrm{O}, 2 \mu \mathrm{g}$ biotin, $0.4 \mathrm{mg}$ calcium pantothenate, $2 \mathrm{mg}$ inositol, $0.4 \mathrm{mg}$ thiamin. $\mathrm{HCl}, 18 \mathrm{mg}$ adenine, $10 \mathrm{mg}$ histidine. $\mathrm{HCl}, 20$ mg DL-tryptophan, $30 \mathrm{mg} \mathrm{KH} \mathrm{PO}_{4}, 250 \mathrm{ml} \mathrm{0.2} \mathrm{M-citrate} \mathrm{buffer} \mathrm{(pH} \mathrm{4.0)} \mathrm{and} 1 \mathrm{ml}$ polypropylene glycol (mol. wt 2000). Skim milk agar plates $(15 \mathrm{ml})$ with or without $625 \mathrm{mg}$ sodium azide $\mathrm{l}^{-1}$ were prepared as described by Ogrydziak \& Mortimer (1977).

Media for the nitrogen regulation experiments contained (per litre): $20 \mathrm{~g}$ glycerol, $30 \mathrm{mg}$ adenine and $1.42 \mathrm{~g}$ nitrogen supplied as $2.24 \mathrm{~g}$ YNB without amino acids or as $1.7 \mathrm{~g}$ YNB without amino acids and ammonium sulphate plus $3.05 \mathrm{~g}$ urea (filter-sterilized) or $13.3 \mathrm{~g}$ leucine or $14.9 \mathrm{~g}$ glutamic acid.

Examination of extracellular proteins. Sample preparation. Culture supernatants $[130 \mathrm{ml}$ from two $75 \mathrm{ml}$ cultures grown in GPP (pH 6.8) in $500 \mathrm{ml}$ baffled flasks] were collected at a cell density of 1 to $2 \mathrm{mg} d r y$ wt cells ml $\mathrm{ml}^{-1}$ and concentrated (ultrafiltration with an Amicon Diaflo UM 10 membrane) to 1 to $2 \mathrm{ml}$. Cell density was measured using a Klett-Summerson photoelectric colorimeter with a green filter. A Klett reading of 250 corresponded to $1 \mathrm{mg}$ dry wt cells $\mathrm{ml}^{-1}$. For some later experiments the protease samples were prepared for SDS-PAGE using trichloroacetic acid (TCA) precipitation. Cells were grown in modified GPP (pH 6.8) medium (the glycerol and Proteose-peptone concentrations were increased by $50 \%$ ) and the supernatant was collected at a cell density of 1.8

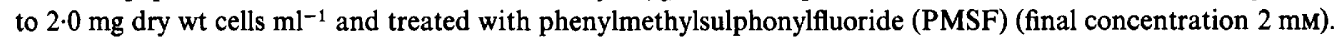
Ice-cold $50 \%$ (w/v) TCA was added to $20 \mathrm{ml}$ of the supernatant to a final TCA concentration of $5 \%(\mathrm{w} / \mathrm{v})$. The pellet was washed once with $5 \%(\mathrm{w} / \mathrm{v}) \mathrm{TCA}$ and redissolved in $300 \mu \mathrm{l}$ of loading buffer and up to $20 \mu \mathrm{l} 2 \mathrm{M}-\mathrm{NaOH}$ was added to readjust the $\mathrm{pH}$ to near neutrality.

Alkaline protease assay. Activity was measured using the agar diffusion method described by Ogrydziak \& Scharf (1982).

SDS-PAGE. Extracellular protein preparations were treated with $2 \mathrm{mM}-\mathrm{PMSF}$, boiled for $5 \mathrm{~min}$ in $2 \%(\mathrm{w} / \mathrm{v})$ SDS, $8 \mathrm{M}$-urea and $1 \%(\mathrm{v} / \mathrm{v})$ mercaptoethanol and dialysed overnight in $0.1 \mathrm{M}$-Tris/ $\mathrm{HCl}$ buffer $\mathrm{pH} 6.8$ with $2 \%$ $\operatorname{SDS}(w / v)$. Samples were resolved on 10 or $12.5 \%(w / v)$ polyacrylamide slab gels $(1.5 \mathrm{~mm}, 10 \times 14 \mathrm{~cm})$ containing SDS using the system described by Laemmli (1970). Typically 20 to $30 \mu \mathrm{g}$ of protein was loaded per well in a volume of 100 to $150 \mu \mathrm{l}$. Protein concentration was determined by the dye-binding assay of Bradford (1976) with bovine serum albumin as the standard. A $4.5 \%$ stacking gel was used and slabs were stained with Coomassie Brilliant Blue R. The gels were run at $15^{\circ} \mathrm{C}$ at $8 \mathrm{~mA}$ per gel during stacking and then at $20 \mathrm{~mA}$ per gel.

Isoelectric focusing. Active and PMSF-inactivated extracellular protein preparations were resolved on $7 \cdot 5 \%$ polyacrylamide slab gels $(1.5 \mathrm{~mm}, 10 \times 14 \mathrm{~cm})$ containing $2 \%(\mathrm{v} / \mathrm{v})$ Pharmalyte $(\mathrm{pH} 5$ to 8$)$ or $2 \%(\mathrm{v} / \mathrm{v}) \mathrm{LKB}$ Ampholine (pH 6 to 8), using chemical polymerization and the gel composition described by Wrigley (1971). Samples were mixed with equal volumes of $2 \%(\mathrm{v} / \mathrm{v})$ ampholyte in $70 \%(\mathrm{w} / \mathrm{v})$ sucrose and $45 \mu \mathrm{l}$ volumes were loaded per well. The samples were overlayed with running gel which was then polymerized to 'cap' the sample. Gels were focused at $4{ }^{\circ} \mathrm{C}$ at constant power of $0.32 \mathrm{~W}$ per gel for 24 to $26 \mathrm{~h}$ and $0.4 \mathrm{~W}$ per gel for $1 \mathrm{~h}$. The $\mathrm{pH}$ gradient was determined using a flat head electrode (Beckman). The gels were placed in a TCA and sulphosuccinic acid solution for $1 \mathrm{~h}$ and were stained with Coomassie Brilliant Blue $\mathbf{R}$.

Thermal stability. The thermal stability of the protease from both the concentrated supernatants from the xpr mutants and for the unconcentrated supernatants from the xpr revertants was examined using the agar diffusion assay on skim milk plates (Simms \& Ogrydziak, 1981). The sizes of the zones of clearing on plates incubated at $23^{\circ} \mathrm{C}$ and $40^{\circ} \mathrm{C}$ were compared.

Isolation and characterization of revertants of xpr mutants. Spontaneous and ultraviolet light $\left(24 \mathrm{~J} \mathrm{~m}^{-2}\right)$ induced revertants were isolated by spreading about $10^{5}$ to $10^{6}$ cells on skim milk agar plates. Possible XPR ${ }^{+}$revertants which formed distinct colonies surrounded by zones of clearing (indicative of protease activity) were picked and streaked on skim milk agar plates. An isolated XPR ${ }^{+}$colony was transferred to $\mathrm{YM}$ plates which were incubated at $23^{\circ} \mathrm{C}$ for $24 \mathrm{~h}$. The YM-grown isolates were inoculated on to skim milk plates by making a small stab with a toothpick and were replica plated on to SM plus adenine plates. Duplicate plates were incubated at 23 and $33^{\circ} \mathrm{C}$ for $48 \mathrm{~h}$ 
and sizes of the zones of clearing recorded. Only those isolates which grew on the SM plus adenine plates at $33^{\circ} \mathrm{C}$ were characterized further.

Acid protease assay. Cells grown overnight in acidified $\mathrm{YM}$ at $23^{\circ} \mathrm{C}$ in a roller drum were inoculated into $125 \mathrm{ml}$ baffled flasks containing $20 \mathrm{ml} \mathrm{GPP}$ (pH 3.4) medium. Cultures were grown at $25^{\circ} \mathrm{C}$ with aeration. Samples were taken during exponential growth at a cell density of 2.0 to $2.4 \mathrm{mg}$ dry wt cells ml $\mathrm{m}^{-1}$ and acid protease activity of the supernatant was measured. Supernatant $(0.4 \mathrm{ml})$ and $3.0 \mathrm{ml}$ of $0.5 \%(\mathrm{w} / \mathrm{v})$ acid-denatured haemoglobin in acetate/ phosphate/EDTA buffer at pH 3.5 (Larson \& Whitaker, 1970) were combined and incubated for $1 \mathrm{~h}$ at $25^{\circ} \mathrm{C}$. The reaction was stopped with $3.0 \mathrm{ml}$ of $10 \%(\mathrm{w} / \mathrm{v})$ TCA, the precipitate filtered, and $1.0 \mathrm{ml}$ of the filtrate was assayed by the Lowry procedure (Herbert et al., 1971). A protease unit was defined as the amount of protease causing an increase in absorbance at $750 \mathrm{~nm}$ of 0.1 after $1 \mathrm{~h}$. Assays were done in triplicate.

Phosphatase production. Cultures were grown for $24 \mathrm{~h}$ in $5 \mathrm{ml}$ of low phosphate medium at room temperature in a roller drum. Cells were centrifuged $(12000 \mathrm{~g}$ for $10 \mathrm{~min})$, washed with low phosphate medium, resuspended in the same medium, and inoculated into $50 \mathrm{ml}$ of low phosphate medium in a $500 \mathrm{ml}$ baffled flask to give an initial cell density of $25 \mathrm{Klett}$ units. The cultures were grown at $23^{\circ} \mathrm{C}$ with aeration. At appropriate cell densities, samples were withdrawn and centrifuged $(12000 \mathrm{~g}$ for $10 \mathrm{~min})$. The supernatant was removed and the cells were suspended to the original volume in $10 \mathrm{~mm}$-sodium azide and diluted to a final cell density of about $17 \mathrm{Klett}$ units.

Phosphatase assay. Acid phosphatase production was tested on agar plates using the histochemical test for acid phosphatase and low and high phosphate agar medium described by Hansche et al. (1978). Phosphatase assays of culture supernatants and washed cell suspensions were done using a modification of the method of van Rijn et al. (1972). Prewarmed diluted cell suspension or supernatant $(0.25 \mathrm{ml})$ was added to $0.75 \mathrm{ml}$ of prewarmed substrate solution ( $3.5 \mathrm{mg}$ p-nitrophenyl phosphate in $1 \mathrm{ml} 0.1 \mathrm{M}$-citrate buffer, $\mathrm{pH} 6.5$ ). The mixture was incubated at $35^{\circ} \mathrm{C}$ for $15 \mathrm{~min}$ and the reaction was stopped by adding $4 \mathrm{ml} 0.2 \mathrm{M}-\mathrm{NaOH}$. Samples were assyed in triplicate. A blank was run simultaneously by reversing the order of addition of substrate and $\mathrm{NaOH}$. Absorbance was read at $410 \mathrm{~nm}$. One unit of enzyme activity was defined as the amount of enzyme required to form $1 \mathrm{nmol}$ of product in 1 min under the above conditions.

The $\mathrm{pH}$ optimum was determined using the assay described above except that the substrate was dissolved in one of the following buffers $(0 \cdot 1 \mathrm{M}$ concentration): citrate, acetate, MES, HEPES or Tris.

Nitrogen regulation. Cultures grown in YM medium were washed and resuspended at a cell density of $500 \mathrm{Klett}$ units. Then $0.1 \mathrm{ml}$ of the cell suspension was added to $5 \mathrm{ml}$ of the media with ammonia, urea, leucine or glutamic acid as the sole nitrogen source and the cultures incubated at $23^{\circ} \mathrm{C}$ with aeration. Klett readings were taken at 24 and $48 \mathrm{~h}$.

\section{RESULTS \\ Extracellular protease characterization}

Some structural gene and processing gene mutations would result in the production of an altered protease. Therefore, the $x p r$ mutants were characterized by examining the extracellular proteins (especially the alkaline protease) they produced. Concentrated supernatants from the cultures grown in GPP ( $\mathrm{pH}$ 6.8) medium were examined by isoelectric focusing and SDSPAGE. On the isoelectric focusing gels, one major protein band appeared for the wild-type (Fig. 1 , lane A). This protein had an isoelectric point identical to that of the purified alkaline protease (results not shown) and this protein had proteolytic activity [detected by laying strips from the isoelectric focusing gel on agar containing skim milk ( $\mathrm{pH} \mathrm{6.8)} \mathrm{and} \mathrm{looking} \mathrm{for} \mathrm{bands} \mathrm{of} \mathrm{clearing].}$ On the SDS-PAGE gels, the major protein band for the wild-type (Fig. 1, lanes D and G) had a molecular weight equal to that of the purified alkaline protease (results not shown). Based on these results and the fact that in GPP medium the protein secreted into the medium in the largest amounts is the alkaline protease (Ogrydziak \& Scharf, 1982), we conclude that the major band is the alkaline protease.

All the xpr mutants were examined on isoelectric focusing gels and those producing a protease band were also examined by SDS-PAGE. For some $x p r$ mutants no protease band was detected, and the amount produced by the other mutants (estimated by visual inspection of band intensity) correlated fairly well with the level of alkaline extracellular protease activity produced. A heavy protease band from a supernatant with little protease activity would suggest that a protease of altered specific activity had been produced. Examples of the results are shown in Fig. 1. No discernible protease band was produced by $x p r 9-8$ (lane $\mathrm{C}$ ), the structural gene mutant xpr 2-33 (lane F) or xpr 1-5 (lane I). A faint band was produced by xpr3-16 (lane E) and a revertant of xprl-5 (lane $\mathrm{H}$ ) produced a heavy band. 


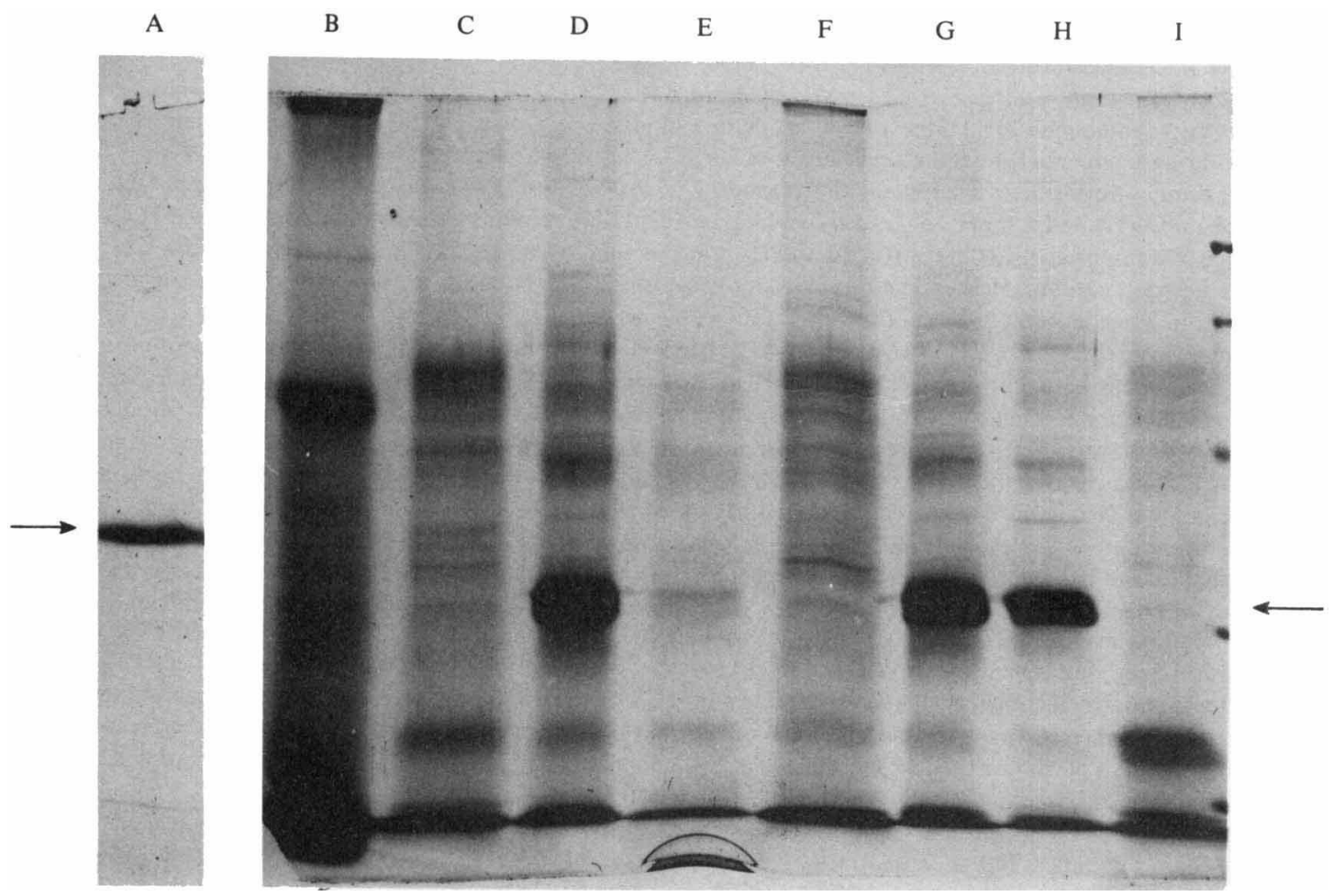

Fig. 1. Lane A, isoelectric focusing (Pharmalyte $\mathrm{pH}$ 5-8) of $22 \mu \mathrm{l}$ of a 110-fold concentrated wild-type supernatant collected at 275 Klett units. Lanes B to I, SDS-PAGE $(10 \%$, w/v acrylamide $)$ of TCA precipitates. Lane B is $150 \mu \mathrm{l}$ of TCA precipitated, uninoculated GPP medium; lanes D and G are $25 \mu 1$ of wild-type; lane $\mathrm{C}$ is $150 \mu \mathrm{l}$ of $x p r 9-8$; lane $\mathrm{E}$ is $150 \mu \mathrm{l}$ of $x p r 3-16$; lane $\mathrm{F}$ is $150 \mu \mathrm{l}$ of $x p r 2-33$; lane $\mathrm{I}$ is $150 \mu \mathrm{l}$ of $x p r 1-5$ and lane $\mathrm{H}$ is $30 \mu \mathrm{l}$ of a revertant of $x p r l-5$. The arrows indicate the position of the protease.

The proteases produced by the $x p r$ mutants and the wild-type were indistinguishable on the isoelectric focusing or SDS-PAGE gels. The protease has a pI of 5.7 and a molecular weight near 35000 as estimated by SDS-PAGE (Ogrydziak \& Scharf, 1982). In the pH 5 to 6 region of the isoelectric focusing gels, a difference in $\mathrm{pI}$ of $0 \cdot 1$ should have resulted in about a $4 \mathrm{~mm}$ difference in protease mobility. In the 30000-40000 molecular weight region of the SDS gels, a difference in molecular weight of 2000 should have resulted in about $4 \mathrm{~mm}$ difference in protein mobility. Protease production of mutant xpr6-13 had been shown to be salt $(0.5 \mathrm{M}-\mathrm{KCl})$ correctable (Ogrydziak \& Mortimer, 1977). When grown without added $\mathrm{KCl}$, xpr6-13 produced no detectable protease protein band which suggests that the $\mathrm{KCl}$ affected protease production and not activity. Similar results were obtained when column chromatography was used to detect the protease protein peak (unpublished results).

The concentrated supernatants from all the xpr mutants, except for xpr6-13 and xpr-15, contained sufficient protease activity for the thermal stability comparisons. This screening led to the discovery of the temperature sensitivity of the xpr2-7 protease. This finding supported other evidence which proved that $x p r 2$ was the structural gene for the alkaline extracellular protease (Simms \& Ogrydziak, 1981). All the other proteases produced by the xpr mutants had thermal stability indistinguishable from the wild-type protease.

\section{Revertants}

Isolation of spontaneous and UV-induced revertants of the xpr mutants was undertaken in an effort to obtain mutants, not in the structural gene, which produced a temperature-sensitive protease. Such a mutant would produce an altered protease because a gene affecting processing of the protease was mutated. 
Table 1. Isolation of revertants of xpr mutants and determination of temperature sensitivity of protease production and protease activity

\begin{tabular}{|c|c|c|c|c|c|c|}
\hline \multirow[b]{2}{*}{ Strain } & \multicolumn{2}{|c|}{ Frequency } & \multicolumn{2}{|c|}{$\begin{array}{l}\text { No. of } \\
\text { revertants } \\
\text { recovered }\end{array}$} & \multicolumn{2}{|c|}{$\begin{array}{c}\text { Frequency of temperature } \\
\text { sensitivity* }\end{array}$} \\
\hline & $\begin{array}{l}\text { Without } \\
\text { UV }\end{array}$ & $\begin{array}{l}\text { With } \\
\text { UV }\end{array}$ & $\begin{array}{l}\text { Without } \\
\text { UV }\end{array}$ & $\begin{array}{l}\text { With } \\
\text { UV }\end{array}$ & $\begin{array}{l}\text { Protease } \\
\text { production }\end{array}$ & $\begin{array}{c}\text { Protease } \\
\text { activity }\end{array}$ \\
\hline xprI-5 & $7 \times 10^{-8}$ & $2 \times 10^{-7}$ & 2 & 17 & $3 / 17$ & $0 / 1$ \\
\hline$x p r 1-14$ & & $6 \times 10^{-7}$ & & 2 & $0 / 2$ & $0 / 1$ \\
\hline$x p r 2-7$ & & $<2 \times 10^{-8}$ & & & & \\
\hline$x p r 2-9$ & & $<2 \times 10^{-8}$ & & & & \\
\hline$x p r 2-33$ & & $<2 \times 10^{-8}$ & & & & \\
\hline$x p r 2-34$ & & $<3 \times 10^{-8}$ & & & & \\
\hline xpr3-16 & & & $>50 \dagger$ & & $21 / 21$ & $0 / 5$ \\
\hline xpr4-18 & & $3 \times 10^{-6}$ & & 8 & $5 / 8$ & $0 / 2$ \\
\hline xpr6-13 & $<5 \times 10^{-8}$ & & & & & \\
\hline xpr6-25 & & $<1 \times 10^{-7}$ & & & & \\
\hline$x p r 8-10$ & $<2 \times 10^{-7}$ & $6 \times 10^{-6}$ & & 18 & $5 / 18$ & $0 / 3$ \\
\hline xpr9-8 & $1 \times 10^{-6}$ & $4 \times 10^{-5}$ & 8 & 127 & $0 / 40$ & $0 / 1$ \\
\hline$x p r-15$ & & & $21 \dagger$ & & $0 / 21$ & $0 / 2$ \\
\hline
\end{tabular}

For mutants which were leaky for protease production on skim milk plates $(x p r 5, x p r 7$ and $x p r 10$ ) the heavy background growth made isolation of revertants impossible. Of the non-leaky mutants, revertants were isolated for all but $x p r 2$ and $x p r 6$ (Table 1). Some of the revertants were temperature sensitive for protease production. However, in no case was the protease itself temperature sensitive (Table 1). All 59 of the segregants of a cross between the revertant of xpr $1-5$ and wild-type were $\mathrm{XPR}^{+}$at $23^{\circ} \mathrm{C}$ which indicates that this revertant was probably not due to an extragenic suppressor.

\section{Acid protease production}

Four of the xpr mutants (xpr1, 3, 4 and 8) had been shown to produce not only low levels of alkaline extracellular protease but also reduced levels of extracellular RNAase(s) (Ogrydziak \& Mortimer, 1977). These results suggested that these xpr mutations were not specific for the protease. To further investigate the pleiotropic nature of the xpr mutants, their acid extracellular protease production was examined.

At least three extracellular acid proteases are produced by $S$. lipolytica $(\mathrm{pH}$ optima are $\mathrm{pH} 3 \cdot 1$, 3.5 and 4.2 ), and the relative amounts vary during exponential growth (T. Yamada, personal communication). Cultures were assayed in the mid-exponential growth phase. Acid protease activity was measured at $\mathrm{pH} 3 \cdot 5$.

The results shown in Table 2 confirm that the four $x p r$ mutations affecting extracellular RNAase production also affect extracellular acid protease production. All four xpr mutants produce greatly reduced amounts of extracellular acid protease activity while, as expected, the $x p r 2$ structural gene mutants produce wild-type levels. The $x p r 5$ mutants, which were largely unaffected for extracellular RNAase production, produced about $50-60 \%$ of wild-type levels of the acid extracellular protease(s). Therefore, at least five of the eleven $x p r$ mutations are not specific for the alkaline extracellular protease but affect production of one or more other secreted enzymes.

\section{Phosphatase production}

Much of the information on protein secretion in Sacch. cerevisiae was obtained from studies of mutants affected in secretion of acid phosphatase and invertase. Novick \& Schekman (1979) assumed that mutants temperature sensitive for secretion would be temperature sensitive for 


\section{Table 2. Production of secreted enzymes by xpr mutants}

Enzyme production was determined as units per mg dry wt cells. Values are units per mg dry wt cells and are expressed as either specific activities (sp. act.) or differential rates (diff. rate).

\begin{tabular}{|c|c|c|c|c|c|c|c|}
\hline \multirow[b]{2}{*}{ Strain } & \multirow{2}{*}{$\begin{array}{l}\text { Alkaline } \\
\text { protease } \\
\text { (sp. act.)* }\end{array}$} & \multirow{2}{*}{$\begin{array}{l}\text { RNAase } \\
\text { (sp. act.)* }\end{array}$} & \multirow{2}{*}{$\begin{array}{c}\text { Acid } \\
\text { protease } \\
\text { (sp. act.) }\end{array}$} & \multicolumn{2}{|c|}{ Phosphatase $\dagger$} & \multicolumn{2}{|c|}{ Phosphatase $†$} \\
\hline & & & & (sp. act.) & $\mathrm{n}$ & (diff. rate) & $\mathrm{n}$ \\
\hline Wild-type & 131 & 103 & 31 & $426(100)$ & 7 & $500(100)$ & 12 \\
\hline$x p r 1-5^{\circ}$ & 0.0 & 38 & $1 \cdot 4$ & $390(92)$ & 2 & 477 (99) & 3 \\
\hline$x p r 1-14$ & $1 \cdot 0$ & 42 & $1 \cdot 3$ & 392 (103) & 2 & $546(105)$ & 3 \\
\hline$x p r 2-7$ & 6.7 & 101 & 26 & $403(86)$ & 1 & & \\
\hline$x p r 2-9$ & $0 \cdot 1$ & 79 & 33 & $381(103)$ & 1 & & \\
\hline$x p r 2-32$ & $6 \cdot 1$ & $\mathrm{WT}_{+}^{+}$ & 28 & $337(80)$ & 1 & & \\
\hline$x p r 2-33$ & 0.0 & WTt & 30 & $321(86)$ & 1 & 565 (117) & 2 \\
\hline$x p r 2-34$ & 0.0 & $\mathrm{WT}_{+}^{+}$ & 35 & $521 \quad(92)$ & 1 & & \\
\hline xpr3-16 & 39 & $35^{\circ}$ & $2 \cdot 5$ & $392(84)$ & 2 & $333(65)$ & 2 \\
\hline xpr3-23 & 67 & 37 & 14 & $423(91)$ & 2 & 488 (116) & 1 \\
\hline xpr4-18 & $1 \cdot 6$ & 21 & $1 \cdot 7$ & 477 (111) & 2 & $273(67)$ & 2 \\
\hline$x p r 4-21$ & 13 & 96 & $2 \cdot 9$ & $282(66)$ & 3 & $237(50)$ & 2 \\
\hline$x p r 5-2$ & $1 \cdot 3$ & 88 & 18 & & & & \\
\hline xpr5-11 & $7 \cdot 9$ & 84 & 18 & $233(63)$ & 1 & 401 (74) & 1 \\
\hline xpr5-22 & $6 \cdot 1$ & 88 & 16 & $310(78)$ & 1 & & \\
\hline xpr6-13 & $0 \cdot 1$ & 83 & 26 & $295(77)$ & 2 & & \\
\hline xpr6-25 & 0.5 & & 28 & $525(133)$ & 1 & & \\
\hline$x p r 7-3$ & 74 & 74 & 34 & $226(66)$ & 1 & $352(65)$ & 1 \\
\hline$x p r 8-10$ & $3 \cdot 8$ & 40 & 2.9 & 441 (78) & 1 & $392(76)$ & 2 \\
\hline xpr9-8 & $3 \cdot 4$ & 80 & 31 & $333(97)$ & 1 & & \\
\hline xpr10-4 & 12 & 81 & 30 & $395(115)$ & 1 & & \\
\hline$x p r-15$ & $1 \cdot 6$ & 73 & 27 & & & & \\
\hline
\end{tabular}

* Data from Ogrydziak \& Mortimer (1977) and Simms \& Ogrydziak (1981).

$\dagger$ The numbers in parentheses are the average of the percentage of wild-type activity obtained within individual experiments. The S.D. of the phosphatase specific activity control was 75 and the S.D. of the differential rate of phosphatase production control was $99 ; \mathrm{n}$ is the number of determinations.

$\ddagger$ Wild-type size zone of RNAase activity on RNA agar plates.

growth. They screened Sacch. cerevisiae mutants temperature sensitive for growth and found secretory mutants. These mutants when shifted to non-permissive temperature stopped secreting acid phosphatase and all other membrane bound or secreted proteins which were examined. The pleiotropic nature of the xpr mutants suggests that they may affect secretion, but the $x p r$ mutants were selected so that they were not temperature sensitive for growth. To better understand this possible contradiction, phosphatase secretion by the xpr mutants was examined.

On agar plates on low phosphate medium the wild-type stained dark red (indicating acid phosphatase activity) and was a light orange on high phosphate medium which indicated repression by phosphate. On low phosphate agar medium, all the xpr mutants stained dark red which suggested that the xpr mutations do not affect phosphatase secretion. However, it was not known whether secretion of low levels of phosphatase might result in dark red staining of the colonies, so phosphatase production was quantified in liquid culture.

The $\mathrm{pH}$ optimum for phosphatase activity of washed cells grown at $\mathrm{pH} 4.0$ in low phosphate medium was about pH 6.7 (Fig. 2) and the optimum for the supernatant was about pH 6.1. Similar $\mathrm{pH}$ optimum values were obtained for washed cells and supernatant from cultures grown at $\mathrm{pH} 6 \cdot 5$. Phosphatase production was originally determined as the specific activity at a cell density of about $500 \mathrm{Klett}$ units since the specific activity appeared fairly constant above $400 \mathrm{Klett}$ units. However, there was substantial variation in the specific activity results within and between experiments. Therefore, in later experiments differential rates of phosphatase production were determined and the variation within experiments decreased. The differential rate was constant above 75 to 100 Klett units (Fig. 4).

Phosphatase production was highly regulated. Wild-type produced 274 units (mg dry wt cells) $)^{-1}$ in low phosphate medium but only 1.9 units (mg dry wt cells $)^{-1}$ in high phosphate medium. At a cell density of 500 Klett units about $91 \%$ of the phosphatase activity was 


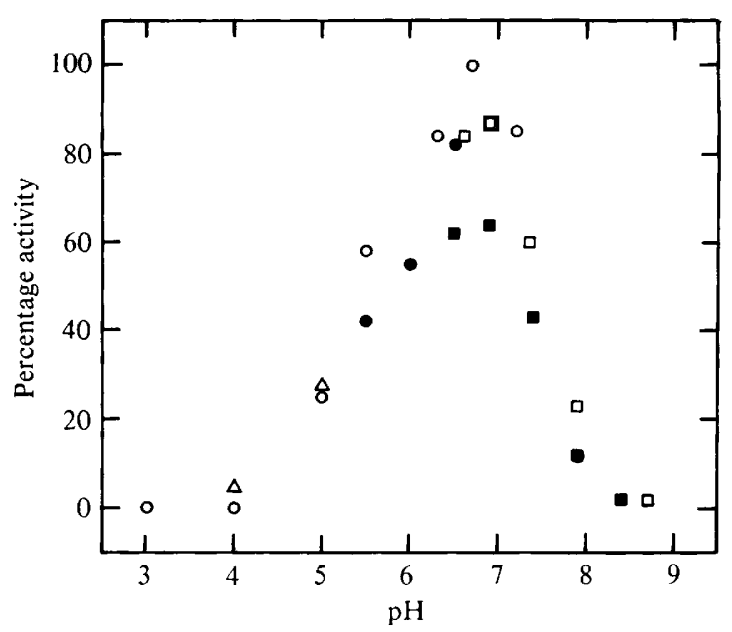

Fig. 2. Effect of pH on cell-bound phosphatase activity of $S$. lipolytica. The buffers used for $\mathrm{pH}$ control were $O$, citrate; $O$, MES; $\square$, Tris; $\square$, HEPES and $\triangle$, acetate.

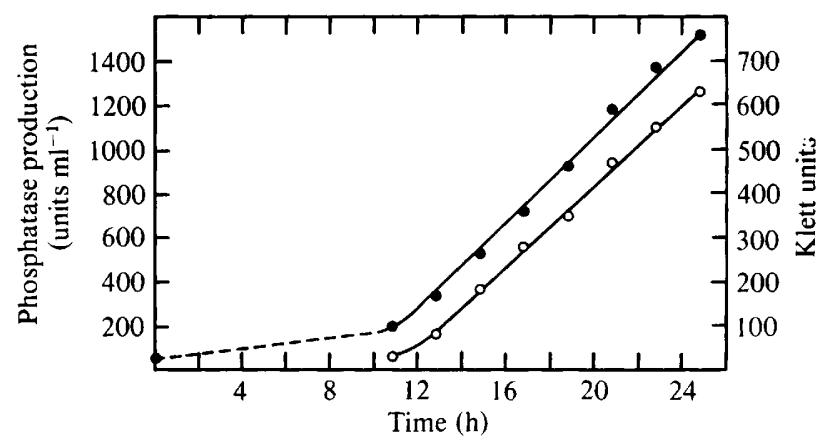

Fig. 3. Phosphatase production $(O)$ and cell growth $(\bullet)$ of wild-type S. lipolytica grown in low phosphate medium.

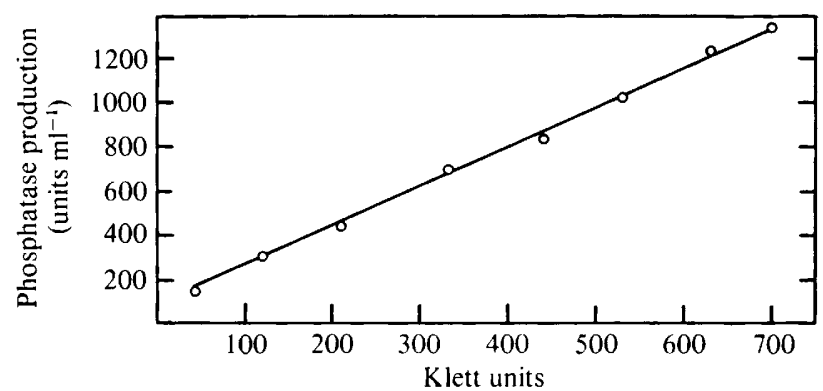

Fig. 4. Data from Fig. 3 replotted to show that the differential rate of phosphatase production [phosphatase units (cell density) ${ }^{-1}$ ] is constant over much of the growth range.

associated with washed cells and $9 \%$ was in the supernatant (10 determinations). Assuming that the $p$-nitrophenyl phosphate does not penetrate the cytoplasmic membrane, then the primary location of the phosphatase activity is the cell envelope.

Phosphatase production was affected in some of the pleiotropic (xpr3, 4, 5 and 8 ) and nonpleiotropic ( $x p r 7$ ) mutants (Table 2), but not to the same extent as production of the other extracellular enzymes. The pleiotropic mutants $x p r 1-5$ and $x p r l-14$ seem to be unaffected for phos- 
phatase secretion. These results suggest that there may be important differences in secretion of the phosphatase(s) and the extracellular proteases and RNAase.

Growth in the low phosphate medium is not exponential (Fig. 3). Many of the xpr mutants grew more slowly than the wild-type in this medium. The reason for this is unclear since the low phosphate medium is a defined medium which does not contain any high molecular weight nutrients. The growth rate of the pleiotropic xpr mutants was compared to wild-type in rich (YM) and in SM plus adenine medium. In YM, all strains grew equally well. In SM plus adenine only xpr1-14 and xpr4-21 grew significantly more slowly, but xpr 1-5 and xpr4-18 grew at wildtype rates which suggests that the slower growth rate was not necessarily due to the xpr mutation.

\section{Nitrogen regulation}

The pleiotropic xpr mutants produce reduced levels of alkaline protease, acid protease(s) and RNAase(s) but produce much nearer to wild-type levels of phosphatase(s). The substrates of the proteases and RNAases, when hydrolysed, can provide nitrogen for the cell. The substrates of the phosphatase generally will not. Possibly one or more of the pleiotropic xpr mutants has a mutation which affects several enzymes involved in nitrogen catabolism. To test this hypothesis, regulation of intracellular enzymes involved in nitrogen catabolism was examined by growing cells in liquid media containing urea, leucine or glutamic acid as sole nitrogen source. The experimental rationale was that a regulatory mutant might not be able to induce or derepress the enzymes needed to grow on a nitrogen source other than ammonia. Mutants xpr1-5, xprl-14, xpr2-7, xpr2-9, xpr2-33, xpr2-34, xpr3-16, xpr3-23, xpr4-18, xpr4-21, xpr6-13, and xpr8-10 were tested and all grew about as well as the wild-type.

\section{DISCUSSION}

The $x p r$ mutants were selected on the basis of their lowered production of extracellular protease activity. Mutations in the protease structural gene or mutations affecting regulation, processing or secretion of the protease could exhibit this phenotype. Processing and structural gene mutations would result in production of altered protease molecules. Mutations in genes affecting regulation or secretion would not.

Proteins can undergo numerous types of post-translational processing (Uy \& Wold, 1977). At least one precursor form of the secreted alkaline protease could be detected inside $S$. lipolytica cells with radioimmune precipitation and SDS-PAGE (J. W. Fukayama \& D. M. Ogrydziak, unpublished data). Whether the conversion of the precursor form to the mature form involved processing of carbohydrate (Esmon et al., 1981), cleavage of a zymogen form of the protease (Hasilik \& Tanner, 1976) or some other event remains to be determined. Besides affecting the molecular weight, failure of this event to occur should result in substantial alteration of the isoelectric point, specific activity and thermal stability of the protease. Such major alterations should have been detectable with the methods employed in this study.

Our results demonstrated that none of the xpr mutants (except xpr2) secreted a detectable amount of the alkaline protease with altered properties. For those revertants temperature sensitive for extracellular alkaline protease production, secretion of a protease with altered thermal stability would have been detected but secretion of an inactive protease would not have been detected. Production of an altered protease by one of the $x p r$ mutants (other than the structural gene mutant $x p r 2$ ) would have been strong evidence that the mutation affected processing of the protease. However, the fact that an xpr mutant does not secrete an altered protease does not eliminate the possibility it still could be a processing mutant. Perhaps, processing is necessary for secretion and altered unprocessed protease cannot be secreted, and the amount of processed protease secreted would be a function of the amount of processing activity present. The revertants for which protease production was temperature sensitive, but for which the protease itself did not have altered thermal stability, could be processing mutants for which the amount or activity of the processing gene product would decrease as the temperature increased. 
The possibility exists that none of the xpr mutants are processing mutants. Processing mutants may be rare or some may be lethal. For example, one type of processing the protease might be expected to undergo would be removal of a signal peptide (Blobel et al., 1979; Perlman \& Halvorson, 1981). It has been suggested that a signal peptidase mutation would be conditionally lethal (Wickner, 1979).

Some regulatory mutants which control several enzymes involved in nitrogen catabolism also control production of extracellular proteases (Arst \& Cove, 1973; Grove \& Marzluf, 1981). The ability of the pleiotropic $x p r$ mutants to grow as well as wild-type with various nitrogen sources suggests that these $x p r$ mutations do not affect a general nitrogen control circuit.

The presumed xpr secretory mutants were not conditional lethal mutants, and in fact grew as well as wild-type at temperatures where enzyme production was greatly reduced. This result seems to be inconsistent with the results for Sacch. cerevisiae secretory mutants for which cell surface growth was stopped at non-permissive temperatures (Novick \& Schekman, 1979; Novick et al., 1980). The apparent contradiction may be explained by a finding of Mehta \& von Borstel (1979) who did complementation testing of $11 \mathrm{~S}$. lipolytica mutants (temperature sensitive for growth) which also affected extracellular protease and RNAase production at permissive temperature. In this group of 11 mutants they found representatives of each of the pleiotropic xpr mutations (xpr1, 3, 4 and 8). Therefore, these xpr mutations may affect enzyme secretion more severely than cell growth, and whether or not one of these mutants will be temperature sensitive for growth will depend on the leakiness of the mutation. Perhaps, secretion of phosphatase also was less dependent on the gene products of these xpr mutants than was secretion of the proteases. One Sacch. cerevisiae secretory mutant described by Novick et al. (1980) affected acid phosphatase secretion but not invertase secretion.

Alternatively, the non-conditional nature of the presumed secretory xpr mutants could be explained by multiple secretion pathways if one assumes that the extracellular proteases and RNAases are not secreted along the same pathway(s) as the phosphatase(s) or cell surface components.

At the cell densities used for the acid protease assays, for the wild-type, the three acid proteases contribute about 8,11 and 12 units of proteolytic activity $\mathrm{ml}^{-1}$, measured at $\mathrm{pH} 3 \cdot 5$ (T. Yamada, personal communication). Therefore, the $x p r$ mutants (xpr 1, 3, 4 and 8 ) which produce less than 8 units $\mathrm{ml}^{-1}$ must be producing reduced levels of all three acid proteases.

The $S$. lipolytica phosphatase(s) have not been studied previously. The shape of the $\mathrm{pH}$ activity curve (Fig. 2) suggests that only one phosphatase is present, but the number and nature of the phosphatase(s) is not known. It is assumed that the phosphatase activities in the cell envelope and in the supernatant are due to the same enzyme(s) and that the differences in $\mathrm{pH}$ optimum are due to differences in the local environment during the assay. In any case, most of the phosphatase activity is located in the cell envelope and not in the extracellular medium as is also true for the acid phosphatase(s) of Sacch. cerevisiae (McLellan \& Lampen, 1963).

The results on production of extracellular acid proteases further support the possibility that $x p r 1,3,4$ and 8 affect secretion. Their lack of effect (xprI) or limited effect (xpr3, 4 and 8 ) on phosphatase production is a major finding of this study. One possible explanation for why these presumed secretory mutants have limited or no effect on phosphatase secretion is that at least one step (component) of the secretion pathway for the extracellular enzymes is not shared by the cell-bound phosphatase(s). Another explanation is that some of the pleiotropic xpr mutations affect a processing activity required for secretion of the proteases and RNAases but not the phosphatase(s).

In conclusion, these results suggested that the pleiotropic xpr mutations were in genes involved in secretion or perhaps processing of several secreted proteins and not in genes involved in general regulation of nitrogen catabolism. None of the mutants could be shown to be processing mutants by examination of their secreted proteins. Based on these results, investigation of the properties of the alkaline protease inside rather than outside the cell should be a better approach for characterizing these mutants. Such studies have been initiated.

These results also suggested the possibility that one or more steps (components) of the secretory pathway were not shared by the proteases and phosphatases. We are investigating the 
possibility that such a component might be a gene product, needed for the release of the extracellular enzymes from the cell wall matrix, which is inactivated in the pleiotropic mutants.

We thank G. Tanimoto, A. Hoq and P. Simms for preliminary characterization of the revertants and J. W. Fukayama for running several gels. The work was supported by grants PCM78-03191 and PCM80-11510 from the National Science Foundation and by Agricultural Experiment Station fund CA-D-FST-3590-H.

\section{REFERENCES}

ARst, H. N. \& Cove, D. J. (1973). Nitrogen metabolite repression in Aspergillus nidulans. Molecular and General Genetics 126, 11-141.

Blobel, G., Walter, P., Chang, C. N., Goldman, B. M., ERICKSON, A. H. \& LiNGAPPA, V. R. (1979). Translocation of proteins across membranes: the signal hypothesis and beyond. Symposia of the Society for Experimental Biology 33, 9-36.

BRADFORD, M. M. (1976). A rapid and sensitive method for the quantitation of microgram quantities of protein utilizing the principle of protein-dye binding. Analytical Biochemistry 72, 248-254.

Esmon, B., Novick, P. \& Schekman, R. (1981). Compartmentalized assembly of oligosaccharides on exported glycoproteins in yeast. Cell 25, 451-460.

Grove, G. \& MARZLUF, G. A. (1981). Identification of the product of the major regulatory gene of the nitrogen control circuit of Neurospora crassa as a nuclear DNA-binding protein. Journal of Biological Chemistry 256, 463-470.

Hansche, P. E., Beres, V. \& Lange, P. (1978). Gene duplication in Saccharomyces cerevisiae. Genetics $\mathbf{8 8}$, $673-687$.

HASILIK, A. \& TANNER, W. (1976). Biosynthesis of carboxypeptidase $\mathrm{Y}$ in yeast. Evidence for a precursor form of the glycoprotein. Biochemical and Biophysical Research Communications 72, 1240-1244.

Herbert, D., Phipps, P. J. \& Strange, E. R. (1971). Chemical analysis of microbial cells. Methods in Microbiology 5B, 209-344.

LAEMMLI, U. K. (1970). Cleavage of structure proteins during assembly of the head of bacteriophage T4. Nature, London 227, 680-685.

LAMPEN, J. O. (1968). External enzymes of yeast: their nature and formation. Antonie van Leeuwenhoek 34, $1-18$.

LARSON, M. K. \& WhitaKeR, J. R. (1970). Endothia parasitica protease. Parameters affecting activity of the rennin-like enzyme. Journal of Dairy Science 53, 253-261.

McLellan, W. L., JR \& Lampen, J. O. (1963). The acid phosphatase of yeast. Localization and secretion by protoplasts. Biochimica et biophysica acta 67, 324 326.

Mehta, R. D. \& von Borstel, R. C. (1979). Genetic regulation of extracellular protease and ribonuclease production in Saccharomycopsis lipolytica. Genetics 91, s80-s81.
Nakase, T. \& Komagata, K. (1968). Taxonomic significance of base composition of yeast DNA. Journal of General and Applied Microbiology 14, 345-357.

Novick, P. \& ScheKMAN, R. (1979). Secretion and cellsurface growth are blocked in a temperaturesensitive mutant of Saccharomyces cerevisiae. Proceedings of the National Academy of Sciences of the United States of America 76, 1858-1862.

Novick, P., Field, C. \& Schekman, R. (1980). The identification of 23 complementation groups required for posttranslational events in the yeast secretory pathway. Cell 21, 205-215.

Novick, P., Ferro, S. \& SChekman, R. (1981). Order of events in the yeast secretory pathway. Cell 25, 461-469.

OGRYdZIAK, D. M. \& Scharf, S. J. (1982). Alkaline extracellular protease produced by Saccharomycopsis lipolytica CX161-1B. Journal of General Microbiology 128, 1225-1234.

OGRYDZIAK, D. M. \& Mortimer, R. K. (1977). Genetics of extracellular protease production in Saccharomycopsis lipolytica. Genetics 87, 621-632.

Perlman, D. \& Halvorson, H. O. (1981). Distinct repressible mRNAs for cytoplasmic and secreted yeast invertase are encoded by a single gene. Cell 25 , 525-536.

Simms, P. C. \& OGRYdziak, D. M. (1981). Structural gene for the alkaline extracellular protease of Saccharomycopsis lipolytica. Journal of Bacteriology 145, 404-409.

Stenderup, A. \& Leth BAK, A. (1968). Deoxyribonucleic acid base composition of some species within the genus Candida. Journal of General Microbiology 52, 231-236.

UY, R. \& WOLD, F. (1977). Posttranslational, covalent modification of proteins. Science 198, 890-896.

VAN Risn, H. J. M., Boer, P. \& Steyn-Parve, E. P. (1972). Biosynthesis of acid phosphatase of baker's yeast. Factors influencing its production by protoplasts and characterization of the secreted enzyme. Biochimica et biophysica acta 268, 431-441.

WICKNER, W. (1979). The assembly of proteins into biological membranes: the membrane trigger hypothesis. Annual Review of Biochemistry 48, 23-45.

WRIGLEY, C. W. (1971). Gel electrofocusing. Methods in Enzymology 22, 559-564. 